\title{
KOMPARASI METODE FIELD TRIP DENGAN METODE CLUSSTERING DALAM PEMBELAJARAN TEKS CERITA PETUALANGAN
}

\author{
Sri Rahayu
}

\author{
Ahli Bahasa dan Sastra Universitas Muhammadiyah Makassar \\ Email: rahayuayyu98@yahoo.co.id
}

\begin{abstract}
ABSTRAK
Pembelajaran teks cerita petualangan dengan menggunakan metode field trip dengan metode clusstering merupakan salah satu materi ajar yang mampu meningkatkan aktivitas belajar, respons belajar dan hasil belajar peserta didik dalam pembelajaran bahasa. Kajian penelitian ini membandingkan metode field trip dengan metode clusstering dalam pembelajaran teks cerita petualangan yang melibatkan dua kelas eksperimen peserta didik. Kelas eksperimen 1 yang terdiri atas 42 orang peserta didik diajar dengan menggunakan metode field trip sedangkan, pada kelas eksperimen 2 yang terdiri atas 42 orang peserta didik diajar dengan menggunakan metode clusstering dengan jumlah pembelajaran sebanyak tiga kali pertemuan per kelas. Data yang dikumpulkan dalam penelitian ini yaitu, data tentang aktivitas peserta didik, respons peserta didik, dan hasil belajar peserta didik. Data hasil penelitian ini dianalisis secara kuantitatif deskriptif dan analisis inferensial.Hasil penelitian ini menunjukkan bahwa pembelajaran menulis teks cerita petualangan peserta didik dengan menggunakan metode field trip dan clusstering sangat efektif. Akan tetapi dari segi aktivitas, respons, dan hasil belajar persentase nilai perlakuan metode clusstering lebih tinggi dibandingkan dengan persentase nilai perlakuan metode field- trip.
\end{abstract}

Kata kunci: Teks cerita petualangan, field trip, dan clustering.

\begin{abstract}
Learning adventure story text using the method clustering field trip is one of the teaching materialst that can increase the activity of learning, learning responses, and learning outcomes of students in language learning. This research study comparing the methods of field trip with clustering method in teaching text adventure story involving two experimental class students. Experiment classes over 422 students taught by using the method on a class field trip while the second experiment consisting of 42 participants taught using methods clustering by learning as much as three times the number of meeting a class. Data collected in this study is data on the activities of learning outcomes of students. The research data was analyzed by quantitative descriptive and inferential analysis. This study has shown that learning to write text adventure stories of learners by using a field trip with clustering method is very effective, but in terms of response and the percentage of the value of learning outcomes clustering method of treatment is higher than the percentage of the value of the treatment methods of the field trip.
\end{abstract}

Keywords:adventure story text, field trip, and clusstering

\section{PENDAHULUAN}

Pembelajaran bahasa Indonesia dalam kurikulum 2013 menjadi pusat integrasi dari semua mata pelajaran, khususnya di sekolah dasar yang mampu membentuk pribadi peserta didik menjadi pribadi lembut, manusiawi, dan 
berkarakter. Hal tersebut sejalan dengan karakteristik kurikulum 2013 yang tercantum dalam Peraturan Menteri Pendidikan dan Kebudayaan No.67 tahun 2013 menyatakan kurikulum 2013 dirancang mengembangkan sikap, pengetahuan, dan keterampilan peserta didik serta menerapkannya dalam berbagai situasi di sekolah dan masyarakat. Posisi Bahasa Indonesia yang sifatnya sentralistik, menjadikannya pusat integrasi dari mata pelajaran IPA dan IPS di sekolah sehingga bahasa Indonesia memiliki gaung yang besar dalam pembelajaran. Hal tersebut diperjelas dalam kompetensi inti kurikulum 2013 yang salah satunya ialah menyajikan pengetahuan dalam bahasa yang jelas, logis dan sistematis, dalam karya yang estetis, serta dalam tindakan yang mencerminkan perilaku anak sehat, beriman, dan berakhlak mulia.

Kurikulum 2013 dalam proses pembelajaran menggunakan pendekatan ilmiah (Scientific Approach), yaitu mengamati, menanya, menalar, mencoba, membentuk jejaring, dan menarik simpulan. Oleh karena itu, keempat aspek keterampilan berbahasa pada kurikulum 2013 tidak disebutkan secara eksplisit seperti pada kurikulum tingkat satuan pendidikan (KTSP) akan tetapi, keterampilan berbahasa tercakup secara menyeluruh di dalam keterampilan menulis. Keterampilan menulis adalah keseluruhan rangkaian kegiatan seseorang mengungkapkan buah pikiran dan perasaannya kepada orang lain atau kepada dirinya sendiri melalui bahasa tulis.

Berdasarkan observasi awal melalui wawancara langsung dengan pesertadidik, yang peneliti laksanakan di SDN Inpres Tamalanrea 1 Makassar hampir $70 \%$ peserta didik di sekolah memandang sebelah mata pelajaran bahasa Indonesia, umumnya peserta didik menempatkan mata pelajaran bahasa pada urutan terakhir dalam pilihan para peserta didik, yaitu setelah pelajaran-pelajaran eksakta dan beberapa ilmu sosial lain. Jarang peserta didik yang menempatkan pelajaran ini sebagai favorit. Sehubungan dengan hal itu, terlihat dengan jelas rendahnya minat peserta didik untuk mempelajarinya dibandingkan dengan mata pelajaran lain. Mereka mengasumsikan bahasa Indonesia adalah bahasa yang selalu mereka pergunakan sehari-hari sehingga mereka kurang berminat terhadap pembelajaran ini. Selama ini pembelajaran bahasa Indonesia di sekolah cenderung konvesional, bersifat hafalan, penuh jejalan teori-teori linguistik yang rumit, dan tidak ramah terhadap upaya mengembangkan kemampuan berbahasa peserta didik. Hal ini khususnya dalam kemampuan membaca dan menulis. Hasil pengamatan juga menunjukkan bahwa pelaksanaan kegiatan menulis hanya berorientasi pada hasil bukan pada proses. Hal tersebut bertolak belakang dengan SKL SD dalam peraturan menteri pendidikan dan kebudayaan No. 54 tahun 2013, yaitu kriteria mengenai kualifikasi kemampuan lulusan yang mencakup sikap, pengetahuan, dan keterampilan.

Kualitas pendidikan sampai saat ini masih tetap merupakan suatu masalah yang paling menonjol dalam setiap usaha pembaharuan sistem pendidikan nasional. Salah satu komponen yang berkenaan dengan masalah kualitas pendidikan adalah kompetensi guru dalam proses belajar mengajar yang belum optimal, baik dari segi penguasaan materi maupun metode terutama dalam mata- pelajaran bahasa Indonesia. Padahal berdasarkan tuntunan Kurikulum 2013 bahasa Indonesia harus dijadikan sentral mata pelajaran di sekolah. Oleh karena itu, salah satu upaya yang dapat dilakukan guru dalam rangka peningkatan mutu pendidikan adalah penerapan berbagai 
metode pembelajaran yang dapat meningkatkan motivasi peserta didik dalam belajar. Metode pembelajaran yang tepat akan membantu guru dalam proses belajar mengajar yang diharapkan dapat memudahkan peserta didik menerima dan memahami materi yang disampaikan khususnya pembelajaran membuat teks cerita.

Berdasarkan uraian tentang berbagai kondisi pembelajaran teks cerita seperti yang diuraikan maka peneliti melakukan sebuah penelitian eksperimen di SDN Inpres Tamalanrea 1, guna mendapatkan metode yang mampu meningkatkan hasil pembelajaran teks cerita petualangan peserta didik dengan membandingkan antara metode field trip dengan metode clustering dalam pembelajaran menulis teks cerita. Kedua metode tersebut dipayungi oleh model pembelajaran projek basic learning yang menggunakan masalah sebagai langkah awal dalam mengumpulkan dan mengintegrasikan pengetahuan baru berdasarkan pengalamannya dalam beraktifitas secara nyata. Sebagaimana diketahui bahwa metode filed trip adalah cara pembelajaran yang dilaksanakan dengan mengajak peserta didik ke suatu tempat atau obyek tertentu di dalam maupun luar sekolah untuk memelajari atau menyelidiki sesuatu, misalnya di taman sekolah, peserta didik mampu menulis teks mengenai keindahan sekolahnya, sedangkan Clustering merupakan pembelajaran teks dengan mengambil satu tema dari lingkungan kemudian merangkaikan kata-kata yang tercipta dari tema tersebut. Misalnya, dari tema laut, peserta didik dapat langsung menuliskan kata-kata pasir, air, perahu, samudera, nelayan, ikan, dan lain-lain. Dari kata-kata itu akan tersusun paragraf

Peneliti mengasumsikan bahwa penerapan metode field trip dan metode clustering dalam pembelajaran akan mampu mengeefektifkan hasil belajar (sikap,pengetahuan, dan keterampilan) peserta didik secara keseluruhan. Asumsi peneliti berlandaskan dari beberapa penelitian yang mengkaji kedua metode tersebut diantaranya penelitian yang dilakukan oleh Sahulekha tahun 2013 "Keefektifan Metode Field Trip dalam Pembelajaran Menulis Deskripsi pada Peserta didik Kelas IV SD Negeri Bogares Kidul 02 Kabupaten Tegal", Fatkur tahun 2012 mengenai "Peningkatan Pembelajaran Pelestarian Alam melalui Metode Field Trip Peserta didik Kelas 3 Sekolah Dasar Kaligayam 02 Kabupaten Tegal", Kurniawati, Catur Rahayu. 2011. "Penerapan metode field trip untuk meningkatkan kemampuan menulis karangan deskripsi pada peserta didik kelas V SDN Bukir Pasuruan". Hasil ketiga penelitian tersebut menunjukkan bahwa penerapan metode Field Trip dapat meningkatkan kemampuan menulis karangan peserta didik, hal tersebut tergambar jelas dari hasil penilaian yang dilakukan masingmasing peneliti. Penelitian tentang metode clustering pernah diterapkan oleh Farihatul, Arofah tahun 2011 "Keefektifan Pembelajaran Menulis Karangan Narasi Berdasarkan Pengalaman dengan Perlakuan Teknik Clustering dan Teknik Modelling Peserta didik Kelas V SD 3 Temulus Mejobo Kudus",Saleh (2007) mengkaji kemampuan peserta didik menulis karangan deskripsi dengan menggunakan pendekatan proses peserta didik SMA 1 Tamalatea dan La Abo (2005) mengkaji pembelajaran menulis kreatif pada peserta didik Madrasah Aliyah Kendari.

Mencermati beberapa karakteristik yang ditampakkan pada penelitian sebelumnya mengenai metode field trip dan metode clustering, peneliti mengasumsikan pembelajaran menulis teks cerita petualangan memiliki kesesuaian dengan kedua metode 
tersebut. Teks cerita petualangan merupakan salah satu jenis teks narasi yang memiliki karakteristik yang berbeda dengan jenis teks narasi lainnya. Sementara guru di SD Inpres Tamalanrea I Makassar menganggap semua pembelajaran teks narasi itu sama dan dapat diajar menggunakan metode yang sama pula, padahal tidak. Hal tersebut, dibuktikan dari rekap nilai peserta didik dalam pembelajaran menulis teks cerita petualangan yang masih belum mencapai KKM yang telah ditentukan. Oleh karena itu, peneliti bermaksud membandingkan kedua metode tersebut pada peserta didik kelas IV SD Inpres Tamalanrea 1 Makassar dalam sebuah penelitian karena, tampaknya belum ada yang mengkaji perbandingan metode field trip dan metode clustering untuk mengefektifkan kemampuan menulis teks cerita petualangan. Peneliti mengasumsikan bahwa penelitian ini perlu diterapkan agar mendapatkan metode yang lebih menunjang hasil menulis dan bermakna dalam pembelajaran yang utamanya berpusat pada peserta didik. Keterlibatan peserta didik secara utuh dalam proses menulis mampu meningkatkan proses dan hasil belajar peserta didik.

\section{LANDASAN TEORI}

\section{Pembelajaran Bahasa}

Bahasa merupakan salah satu unsur penting dalam perkembangan sebuah bangsa, utamanya bagi bangsa Indonesia sebagai alat perekat NKRI yang tidak diragukan lagi. Seperti yang dikatakan oleh seorang pakar bahasa Noam- Chomsky (dalam Purwo, 2000) “ Pengetahuan bahasa atau linguistic competence ini penting karena ini menjadi dasar atau modal untuk kemahiran berbahasa". Oleh karena itu, pembelajaran bahasa Indonesia perlu lebih dikembangkan, baik melalui jalur pendidikan formal maupun nonformal.

Pada kurikulum 2013 posisi bahasa Indonesia sifatnya sentralistik, bahasa Indonesia menjadi pusat integrasi dari mata pelajaran IPA dan IPS di sekolah dasar. Posisi sterategis ini, menjadikan bahasa Indonesia memiliki gaung yang besar. Hal ini tentu akan memicu semakin meningkatnya jiwa nasionalisme para kaum pelajar bangsa, terlepas dari kekurangan-kekurangan yang ada pada wilayah praktisnya di kemudian hari.

Pembelajaran bahasa Indonesia pada dasarnya bertujuan meningkatkan kemampuan peserta didik menggunakan bahasa sebagai alat komunikasi, baik secara lisan maupun tulisan. Hal itu sesuai dengan kompetensi inti mata pelajaran bahasa Indonesia tingkat SD dalam Kurikulum 2013 (Kemdiknas, 2013) yang menyatakan bahwa kompetensi inti mata pelajaran bahasa Indonesia berorientasi pada hakikat pembelajaran bahasa, bahwa belajar bahasa adalah belajar berkomunikasi. Oleh karena itu, pembelajaran bahasaIndonesia diarahkan kepada peningkatan kemampuan peserta didik untuk berkomunikasi dalam bahasa Indonesia, baik secara lisan maupun tulisan.

\section{Menulis}

Menulis merupakan suatu keterampilan berbahasa, dapat diartikan sebagai kemampuan seseorang untuk mengungkapkan pikiran dan idenya kepada orang lain atau kepada dirinya sendiri melalui bahasa tulis. Tarigan (1994:21) menyatakan bahwa: "Menulis adalah menurunkan atau menuliskan lambang-lambang grafem yang menggambarkan suatu bahasa yang dipahami oleh seseorang, sehingga orang lain dapat membaca lambang-lambang grafem tersebut jika mereka memahami bahasa dan gambaran grafem itu." Selanjutnya Enre (1994:5) memberikan 
pengertian bahwa: "Menulis merupakan kegiatan yang dipergunakan untuk berkomunikasi secara tidak langsung." Aktivitas menulis merupakan suatu bentuk menifestasi kemampuan berbahasa paling akhir dikuasai pembelajaran bahasa. Dibandingkan dengan tiga kemampuan berbahasa yang lain, kemampuan menulis lebih sulit dikuasai bahkan oleh penutur asli bahasa yang bersangkutan sekalipun. Hal itu disebabkan kemampuan menulis menghendaki penguasaan berbagai unsur kebahasaan dan unsur di luar bahasa itu sendiri yang akan menjadi isi karangan. Baik unsur bahasa maupun unsur isi haruslah terjalin sedemikian rupa sehingga menghasilkan karangan yang runtut dan padu.

Menulis merupakan suatu

kegiatan yang produktif dan efektif akantetapi dalam menulis juga terdapat berbagai permasalahan menulis sebagaimana dijabarkan bahwa faktor pertama, dari tata kalimat yang tidak beraturan membuat susah dipahami dalam menulis, terutama dalam penyusunan subyek, predikat, obyek sesuai EYD. Faktor kedua, ketidakbiasaan menulis memunculkan kebingungan yang menyebabkan malas dalam menulis. Dan juga dalam menulis kita takut tulisan kita jelek agar tidak terjadi hal tersebut, kita tidak usah memikirkan jelek atau bagusnya tulisan akan tetapi, niatkan dan mencoba untuk sering menulis. Faktor ketiga, sering kali kita mengabaikan tata tulis seperti tanda baca yang membuat kita bingung sendiri dengan tulisan kita yang mengakibatkan salah pemahaman ketika dibaca kembali tulisan tersebut. Agar tidak terjadi hal demikian, sering-seringlah memperhatikan tanda baca ketika kita menulis. Kejelasan menulis bergantung pada pikiran organisasi pemakaian kata dan struktur kalimat ( Morsey, 1976 : 122). Usahakan tata tulisan panjang kalimat yang beraneka ragam, berkarya dengan penuh kegembiraan( Mc. Mahan \& Day; 1960 ). Faktor kelima, sering kali kita malas dalam menulis karena kurangnya minat untuk menulis. untuk menghindari semua itu kita harus memaksakan diri kita untuk menulis walaupun hanya satu paragraf perhari agar mebiasakan diri dalam melatih menulis. Faktor kelima, kurangnya wawasan membuat kita bingung karena tidak adanya inspirasi untuk ditulis. Maka rajin-rajinlah membaca untuk menambah wawasan kita dan banyaknya inspirasi untuk menulis. Faktor keenam, penyajian materi yang terlalu cepat membuat kita sulit untuk mencatat. Untuk itu jika menghadapi situasi dan kondisi seperi ini solusinya kita mendengarkan lalu menulis dengan bahasa sendiri. Faktor ketujuh, rasa kurang percaya diri karena tulisan jelek dan kata-kata yang tidak padu sering kali membuat kita kurang percaya diri ketika menulis. kita harus memotivasi diri dengan mengekspresikan tulisan kita bisa dalam bentuk puisi, cerpen atau syair lagu dan lain-lain. Faktor yang kedelapan menentukan tema, jika kita bingung menentukan tema, teruslah menulis apa yang sedang kita pikirkan dengan sendirinya tema tersebut akan muncul. Atau terlebih dahulu kita membuat kerangka karangan, fokus pada satu tema. Dalam hal ini, kita harus bertindak konkret dan abstrak (Dalam Ducrot dan Todorow, 1981:277).

Berdasarkan permasalahan keterampilan menulis yang diuraikan tersebut maka dalam penelitian ini, peneliti menerapkan dua metode pembelajaran yang masing -masing memiliki kriteria yang handal dalam menuntaskan beberapa permasalahan tersebut. Metode yang dimaksud adalah metode field trip dan metode clusstering .

Berdasarkan karakteristik model pembelajaran kurikulum 2013 maka 
dalam penelitian ini, peneliti mengangkat dua metode pembelajaran yaitu metode field trip dan metode clustering, yang mana jika ditinjau dari langkah pembelajaran dalam kedua metode tersebut peneliti mengasumsikan metode field trip dan metode clustering memiliki kesesuaian dengan salah satu model pembelajaran kurikulum 2013, yaitu project basic learning

\section{Metode Field Trip}

Metode Field trip ialah cara mengajar yang dilaksanakan dengan mengajak peserta didik ke suatu tempat atau obyek tertentu di dalam maupun luar sekolah untuk mempelajari atau menyelidiki sesuatu seperti meninjau pabrik sepatu, suatu bengkel mobil, toko serba ada, peternakan, perkebunan, lapangan bermain dan sebagainya (Roestiyah, 2001:85). Surakhmat (1980: 115-116) mengatakan bahwa metode karyawisata atau field trip adalah metode belajar dan mengajar di mana peserta didik dengan bimbingan guru diajak untuk mengunjungi tempat tertentu dengan maksud untuk belajar. Berbeda halnya dengan tamasya di mana seseorang pergi untuk mencari hiburan semata, field trip sebagai metode belajar mengajar lebih terikat oleh tujuan dan tugas belajar, sedangkan menurut Syaiful Sagala (2006: 214) metode field trip ialah pesiar (ekskursi) yang dilakukan oleh para peserta didik untuk melengkapi pengalaman belajar tertentu dan merupakan bagian integral dari kurikulum sekolah.

Dari beberapa pendapat di atas dapat disimpulkan bahwa metode field trip merupakan metode penyampaian materi pelajaran dengan cara membawa langsung peserta didik ke obyek di luar kelas atau di lingkungan yang berdekatan dengan sekolah agar peserta didik dapat mengamati atau mengalami secara langsung. Dalam pembelajaran Bahasa Indonesia khususnya dalam pelajaran menulis karangan dibutuhkan metodologi pembelajaran yang sesuai dengan kebutuhan dan kondisi peserta didik. Metode field trip dianggap peneliti sebagai salah satu metode yang efektif digunakan sebagai metode pembelajaran khususnya dalam melatih keterampilan menulis teks cerita peserta didik, karena dengan mengamati lingkungan secara nyata peserta didik akan lebih bersemangat dalam mengembangkan ide, pendapat, dan gagasannya ke dalam bentuk tulisan.

\section{Metode Clustering}

Metode Clustering merupakan cara menulis teks dengan mengambil satu tema kemudian merangkaikan kata-kata yang tercipta dari tema tersebut. Misalnya dari tema laut, peserta didik dapat langsung menuliskan kata-kata pasir, air, perahu, samudera, nelayan, ikan, dan lain-lain. Dari kata-kata itu bisa juga tersusun teks cerita. Menurut Gabriele dan Rico dalam Quatum Learning, Deporter dan Hernachi (2003:180) pengelompokan Clustering adalah suatu cara memilih pemikiran yang saling berkaitan dalam menuangkan ide di atas kertas secepatnya, tanpa mempertimbangkan kebenaran atau nilainya.

Sejalan dengan hal tersebut De Porter dan Hernacki (dalam Djumingin:2011) mengemukakan langkah metode clustering yaitu melihat dan membuat kaitan antara gagasangagasan yang berkaitan dengan tema kemudian mengembangkan gagasangagasan tersebut dengan menelusuri jalan pikiran yang ditempuh otak agar mencapai suatu konsep, bekerja secara alamiah dengan gagasan tanpa penyuntingan atau pertimbangan dan menvisualisasikan hal-hal yang khusus 
sembari mengingatnya kembali dengan mudah tanpa mengalami desakan yang kuat untuk menulis.

Berdasarkan langkah metode Clustering dalam pembelajaran peserta didik harus menempatkan setiap kata dalam tingkatan yang sama dengan gagasan yang lain. Ketika peserta didik mencatat atau menerima semua gagasan walaupun semua itu tidak segera memberikan arti, otak dibiarkan terus menghasilkan gagasan-gagasan. Pada dasarnya setiap gagasan adalah gagasan besar, setidaknya potensial untuk menjadi sebuah tulisan yang baik. Pengelompokan kata yang timbul dari asosiasi kata lain akan memudahkan peserta didik menyusun atau menemukan berbagai kosa kata yang memiliki keterkaitan makna. Dengan bekal kumpulan kosa kata tersebut, peserta didik akan mengalami kemudahan untuk membentuk kalimat-kalimat yang efektif dan bermakna. Metode clustering merupakan salah satu jalan mengatasi kemandekan kreativitas peserta didik di dalam menulis teks cerita. Misalnya dari kata istana bisa tersusun kata-kata raja, ratu, putri, pangeran, rakyat,dan sebagainya. Setiap kata dapat dikembangkan menjadi kata atau frasa yang lain. Dalam hal ini tidak semua kata harus dikembangkan atau dipakai.

\section{METODE PENELITIAN}

Penelitian ini adalah penelitian perbandingan eksperimental (experimental- comparison) yang bersifat eksperimen murni. Penelitian diterapkan pada peserta didik kelas IV SDN Inpres Tamalanrea I Makassar tahun pelajaran 2013/2014 yang terdiri atas dua kelas yaitu kelas $\mathrm{IV}_{\mathrm{A}}$ dan $\mathrm{IV}_{\mathrm{B} .}$ Kelas eksperimen 1 yang terdiri atas 42 orang peserta didik diajar dengan menggunakan metode field trip sedangkan, pada kelas eksperimen 2 yang terdiri atas 42 orang peserta didik diajar dengan menggunakan metode clusstering dengan jumlah pembelajaran sebanyak tiga kali pertemuan per kelas. Data yang dikumpulkan dalam penelitian ini yaitu, data tentang aktivitas peserta didik, respons peserta didik, dan hasil belajar peserta didik. Data hasil penelitian ini dianalisis secara kuantitatif deskriptif dan analisis inferensial. Untuk mengumpulkan data yang sesuai dengan penelitian maka penelitian ini menggunakan lembar validasi dan instrumen penilaian. Lembar validasi digunakan untuk menvalidasi perangkat pembelajaran berupa RPP dan buku peserta didik, sedangkan adapun instrumen penilaian yang digunakan untuk mengumpulkan data terdiri dari, lembar observasi aktivitas peserta didik, angket respon peserta didik,dan tes hasil belajar yang telah direvisi oleh beberapa validator guna menvalidasi beberapa instrumen tersebut.

\section{HASIL DAN PEMBAHASAN}

Hasil penelitian ini menunjukkan bahwa, Hasil pengamatan observer terhadap aktivitas peserta didik pada pembelajaran metode field trip dan metode clustering pada kelompok eksperimen 1 dan 2, menunjukkan bahwa dari tujuh aspek yang diamati berdasarkan hasil rata-rata penilaian, ada enam aspek yang memenuhi kategori efektif, yaitu (1)mengamati dengan cermat keberagaman sumber daya alam yang beraneka ragam di lingkungan sekolah, (2)mengajukan pertanyaan pada guru, teman, atau mengadakan wawancara dengan orang yang ada di sekitar lingkungan tempat peserta didik menemukan hal baru yang belum dipahami, (3)mendengarkan informasi yang disampaikan oleh guru selama kegiatan pembelajaran, (4)menjawab pertanyaan atau permasalahan yang 
diberikan oleh guru berdasarkan hal-hal yang peserta didik lihat, dengar, serta mencoba dan membuktikan secara langsung, (5)Perilaku peserta didik sesuai dengan KBM seperti merangkum materi dan bertukar informasi dengan teman sejawat, (6) Menyajikan hasil karya individu dalam bentuk teks cerita petualangan sesuai dengan kaidah EYD, sedangkan aspek mengenai aktivitas peserta didik dalam memelajari hal-hal yang belum dipahami secara intensif dan komprehensif berada pada kategori tidak efektif. Aktivitas peserta didik baik pada kelas eksperimen 1 maupun pada kelas eksperimen 2 berada pada kriteria batasan efektif dan sangat efektif. Ini dapat dilihat pada rata-rata pencapaiana setiap aspek baik pada pembelajaran metode filed trip yang menunjukkan terdapat 14 peserta didik atau sebesar $33,33 \%$ yang memiliki indeks aktivitas belajar yang efektif, yang memiliki indeks aktivitas belajar yang sangat efektif terdapat 28 orang peserta didik atau sebesar $66,66 \%$, jadi $100 \%$ berada pada kategori efektif dan sangat efektif, sedangkan pada pembelajaran metode clusstering berada pada kategori efektif, yang mana $31(73,80 \%)$ peserta didik memiliki indeks aktivitas belajar yang efektif, yang memiliki indeks aktivitas belajar yang sangat efektif terdapat 11 $(26,19 \%)$ peserta didik, jadi $100 \%$ berada pada kategori efektif .

Hasil respons peserta didik, diperoleh bahwa nilai rata-rata respons peserta didik pada metode field trip adalah 3,57 (sangat positif) dan rata-rata metode clusstering adalah 3,21 (positif). Perbedaan nilai rata-rata pada metode field trip dengan metode clusstering, menunjukkan bahwa respons peserta didik dominan lebih tinggi pada perlakuan metode field trip dibandingkan dengan perlakuan metode clusstering.
Hasil belajar peserta didik menulis teks cerita petualangan yang diukur melalui tes awal sebelum dimulainya pembelajaran dan tes akhir sesudah diterapkan pembelajaran metode field trip pada kelas eksperimen 1, maupun pembelajaran metode clusstering pada kelas eksperimen 2 mengalami peningkatan. Pada kelas eksperimen 1, nilai rata-rata tes hasil belajar menulis teks cerita petualangan peserta didik setelah diterapkan pembelajaran metode field trip adalah 75.69 dari nilai ideal 100 dan $100 \%$ peserta didik pada kelas eksperimen 1 telah mencapai ketuntasan. Pada kelas eksperimen 2, nilai rata-rata tes hasil belajar menulis teks cerita petualangan peserta didik setelah diterapkan metode clusstering adalah 82.62 dari nilai idela 100 dan $100 \%$ peserta didik pada kelas eksperimen 2 telah mencapai ketuntasan. akan tetapi nilai hasil belajar peserta didik pada perlakuan metode clusstering lebih tinggi dibandingkan hasil perlakuan metode field trip.

\section{SIMPULAN}

Penerapan metode field trip dan metode clustering dalam pembelajaran teks cerita petualangan peserta didik kelas IV SDN Inpres Tamalanrea 1 Makassar, mampu meningkatkan hasil belajar peserta didik. Akan tetapi ada perbedaan aktivitas belajar peserta didik, respons peserta didik, dan hasil belajar peserta didik antara penggunaan metode field trip dengan metode clusstering. Kesimpulan ini didasarkan pada hasil akhir rata-rata yang menunjukkan bahwa metode field trip dari segi aktivitas adalah 2,59 sedangkan aktivitas peserta didik pada metode clusstering adalah 2,69, rata-rata dari segi respons pada metode field trip berada pada rata-rata 3,17 , sedangkan rata-rata respons terhadap metode clusstering adalah 3,56, 
dan rata-rata hasil belajar peserta didik yang mendapat perlakuan metode field trip adalah 75,69, sedangkan pada metode clusstering rata-rata hasil belajar adalah 82,62.

Dengan demikian, dapat dinyatakan bahwa pembelajaran menulis teks cerita petualangan peserta didik kelas IV SDN Inpres Tamalanrea 1 Makassar dengan menggunakan metode field trip dan clusstering mengalami peningkatan. Akan tetapi dari segi aktivitas, respons, dan hasil belajar persentase nilai perlakuan metode clusstering lebih tinggi dibandingkan dengan persentase nilai perlakuan metode field- trip.

\section{DAFTAR RUJUKAN}

Abo, La. 2005. Strategi Pembelajaran Menulis Kreatif pada Peserta didik Madrasah Aliyah di Kota Kendari. Tesis tidak diterbitkan. Makassar: PPs UNM.

Anwar, Qomari dan Sagala, Syaiful. 2006. Profesi Jabatan Kependidikan Dan Guru Sebagai Upaya Menjamin Kualitas Pembelajaran. Jakarta : Uhamka Press.

Arikunto, Suharsimi. 2006. Prosedur Penelitian Suatu Pendekatan Praktik. Jakarta : Rineka Cipta.

Ary,Donald.,Jacob,Luchy Cheser.,\& Razavieh,Asghar. 1974.

Pengantar Penelitian dalam Pendidikan. Terjemahan oleh Furchan Arief. 2011. Yogyakarta: Pustaka Pelajar.

Bill, Lucas. 1988. Optimalkan Otak Anda. Jakarta: Bhuana Ilmu Populer.
Budianta, Melani, dkk. 2008. Membaca Sastra. Indonesia Tera.

Budiningsih, C.A. (2005). Belajar dan Pembelajaran. Jakarta: Rineka Cipta.

De Porter, Hernachi. 2001. Quantum Learning Membiasakan Belajar Nyaman dan Menyenangkan. Bandung: Kaifa.

Djuanda, Dadang. 2008. Pembelajaran Keterampilan Berbahas Indonesia di SD. Bandung. Pustaka Latifah.

Enre, Fachruddin Ambo. 1994. DasarDasar Keterampilan Menulis. Ujung- Pandang: Badan Penerbit IKIP Ujung Pandang.

Farihatul, Arofah. 2011. Keefektifan Pembelajaran Menulis Karangan Narasi Berdasarkan Pengalaman dengan Perlakuan Teknik Clustering dan Teknik Modelling Peserta didik Kelas V SD 3 Temulus Mejobo Kudus. Skripsi

(Online).http://www.google.com/ url? sa $=\mathrm{t} \& \mathrm{rct}=\mathrm{j} \& \mathrm{q}=\& \mathrm{esrc}=\mathrm{s} \&$ sou rce $=$ web $\& c d=8 \& c a d=r j a \& v e d=0$ CGEQFjAH\&url=http. Diakses 3 Januari 2013.

Fatkur , Tiffany Rizkana. 2012. Peningkatan Pembelajaran Pelestarian Alam melalui Metode Field Trip Peserta didik Kelas 3 Sekolah Dasar Kaligayam 02 Kabupaten Tegal. Tesis (Online). http://lib.unnes.ac.id/18173/. Diakses 21 Januari 2014.

Keraf, Gorys. 2007. Diksi dan Gaya Bahasa. Jakarta: Gramedia Pustaka Utama.

Kurniawati, Catur Rahayu. 2011. Penerapan metode field trip untuk meningkatkan kemampuan menulis karangan deskripsi pada peserta didik kelas V SDN Bukir Pasuruan. Skripsi (Online). 
http://library.um.ac.id/ptk/index. php?mod=detail\&id=49401.

Diakses 17 Januari 2014.

Mahsun. 2013. Pembelajaran Teks dalam

Kurikulum

2013

(Online)http://kemdikbud.go.id/k

emdikbud/artikel-kurikulum-

mahsun.. Diakses 20 Januari

2014.

McMahan, Elizabeth \& Susan Day. 1960.

The Writer's Rhetoric

and Handbook. New

York: McGrawhill Book.

Mini. 2011. Pedoman Pengembangan

Bahan Ajar Tematik

Pendidikan Dasar dan

Karakter Cara Belajar

Sekolah Dasar. Jakarta:

Jaya Abadi.

Morsey, Royal J. 1976. Improving

English Instruction. Chicago:

Rand Mc. Nally College Publishing Company.

Nurdin, 2007. Model Pembelajaran Matematika yang Menumbuhkan

Kemampuan Metakognitif untuk Menguasai Bahan Ajar. Disertasi, Surabaya: Universitas Negeri Surabaya.

Nunan, David. 1991. Language Teaching Metodology a Text Book for Teacher. New York: Prentice Hall.

Ristiani, Lis. 2003. Kajian Apresiasi Prosa Fiksi dan Puisi, Bahan Ajar Perkuliahan Sertifikasi Guru M.Ts. Bandung: IAIN Sunan Gunung Djati.

Roestiyah, 2001, Strategi Belajar Mengajar, Rineka Cipta, Jakarta.

Sahulekha, Dani. 2013. Keefektifan Metode Field Trip dalam Pembelajaran Menulis Deskripsi pada Peserta didik Kelas IV SD Negeri Bogares Kidul 02 Kabupaten Tegal.
Skripsi

(Online).

http://lib.unnes.ac.id/17274/1/1 401409258.pdf. Diakses 21 Januari 2014.

Slamet. 2008. Problematika Pendidikan Tematik.(Online). http://pkgkembang.org/in dex.php?option=com co ntent\&view $=$ article \&id $=$ 1195:pendidikan\&catid $=$ 96:pengunguman-danartikel\&Itemid $=69$.

Diakses 23 Januari 2014.

Surakhmat, Winarno. 1980. Metode Pengajaran Nasional.Bandung: P. Temmars.

Sutirjo dan Sri Istuti Mamik. (2005). Tematik: Pembelajaran Efektif dalam Kurikulum 2004. Malang: Bayumedia Publishing.

Syaiful, Bahri Djamarah dan Aswan Zain. (2006). Strategi Belajar Mengajar. Jakarta: Rineka Cipta.

Tarigan, Henry Guntur. 2008. Menulis. Bandung: Angkasa.

Tompkins, Gail E. 1994. Teaching Writing Balancing Process and Product. New York: Merril and Imprint of Macmilan.

Wahab, Baso. 2008. Peningkatan Kemampuan Menulis Kreatif Puisi Peserta didik Kelas VII SMP Negeri 1 Pangkajene Kabupaten Pangkep dengan Teknik Pengelompokan Kata (clustering). Tesis tidak diterbitkan. Makassar: Program Pascasarjana Universitas Negeri Makassar.

Wardani. 1981. Pengajaran Sastra. Jakarta: Departemen P dan K Jakarta. 